\title{
First report of Phoma sorghina (Sacc.) Boerema Dorenbosch \& van Kest on wheat leaves (Triticum aestivum L.) in Argentina
}

\author{
Analia Edith Perelló \& María Virginia Moreno \\ CONICET -Centro de Investigaciones de Fitopatología (CIDEFI), Facultad de Ciencias Agrarias y Fores- \\ tales de la Universidad Nacional de La Plata. Calle 60 y 119 (1900) La Plata, Pcia. de Buenos Aires, \\ Argentina
}

Received 7 October 2003; accepted in revised form 24 August 2004

\begin{abstract}
A new disease caused by Phoma sorghina has been detected for the first time on wheat plants in the Province of Buenos Aires, Argentina. The pathogen was isolated from wheat leaves growing under field conditions, cultured on PDA and identified by its morphobiometric and cultural characters. The disease symptoms and morphological characters of the pathogen are described. Pathogenicity of the isolate was confirmed by inoculating 10 wheat cultivars under greenhouse conditions.
\end{abstract}

Key words: Argentina, Phoma sorghina, wheat

\section{Introduction}

Phoma sorghina (Sacc.) Boerema, Dorenbosch \& van Kesteren is plurivorous, ubiquitous and common in the tropics and subtropics, causing diseases of cereals and other Gramineae and forage crops [1-7]. Although P. sorghina has been found causing leaf spots in different hosts such as Agave americana, Gossypium hirsutum, Lycium halimifolium, Lycopersicum esculentum, Oryza sativa, Populus nigra, Sorghum spp. and Zea mays, [1-5, 8-12] the disease it causes to aerial parts of plants is of minor importance [5-6]. It causes considerable loss of seedlings of Macroptilum, Stylosanthes and Sorghum through pre and post-emergence death [6].

The fungus has been found on or associated with sorghum grains in the humid Argentinian Pampa [11] but there are no previous reports of its presence upon wheat plants in Argentina and therefore, the confirmation of this fungus as a foliar pathogen of wheat in Buenos Aires Province is significant.

The occurrence of leaf spot diseases of wheat was monitored in Buenos Aires Province, Argentina in 2002. Samples were collected from 12 localities and leaf spot symptoms of an unusual disease were observed in samples from 2 localities, Olavarria and Los Hornos, on experimental field plots with wheat cultivars Buck Poncho and Buck Diamante. The aims of this work are to describe for the first time a new disease contributing to the leaf spot disease complex on wheat plants in Buenos Aires Province, Argentina, to isolate and identify the disease causing agent and to determine its pathogenicity to wheat plants under greenhouse conditions.

\section{Material and methods}

Diseased leaves were collected, stored in paper bags and transported to the laboratory. The pathogen was isolated from typical necrotic lesions by the following method. Small sections of diseased leaves were disinfected in $70 \%$ ethanol and $0.1 \%$ mercuric chloride for $1 \mathrm{~min}$, rinsed twice in sterile distilled water and plated on to $2 \%$ potato-dextrose-agar (PDA). Petri dishes were incubated at $22^{\circ} \mathrm{C}$. To identify the fungus, morphobiometric and cultural studies were conducted with single spore colonies grown on PDA at $20-22{ }^{\circ} \mathrm{C}$ and exposed to a regime 
of $12 \mathrm{~h}$, cool-white fluorescent light and near UV and $12 \mathrm{~h}$ darkness. Inoculation experiments to confirm pathogenicity were performed in the greenhouse at $15-25^{\circ} \mathrm{C}$ and $80 \%$ relative humidity.

Fifteen plants of each of the cvs. Buck Arriero, Buck Poncho, Klein Cacique, Klein Estrella, Prointa Cinco Cerros, Prointa Elite, Prointa Granar, Prointa Guazú, Prointa Imperial and Prointa Puntal were grown in plastic pots $12 \mathrm{~cm}$ diametre containing a potting mix of clay $21.2 \%$; lime $56 \%$; sand $22.8 \%$; soil organic matter $(\mathrm{SOM}) \%=3.35 ; \mathrm{C} \%=1$. Plants were inoculated at the third expanded leaf stage and heading stage. Inoculum was prepared from 10-day-old cultures of $P$. sorghina growing on PDA by flooding each sporulating plate with sterile distilled water and gently scraping the fungal colony with a sterile scalpel to dislodge conidia. The resulting suspension was filtered once through a single layer of cheesecloth, and the spore concentration was determined with a haemocytometer. The spore concentration in inoculum was adjusted to $1 \times 10^{6}$ conidia $/ \mathrm{ml}$. Control plants were sprayed with sterile distilled water. Leaves were sprayed to runoff with a manually operated sprayer. The inoculated plants and controls were kept in a moist chamber for $48 \mathrm{~h}$ and observed daily.

\section{Results and discussion}

The first symptoms appeared $72 \mathrm{~h}$ after inoculation under greenhouse conditions and $15-50 \%$ of plants showed necrotic lesions 10 days after inoculation. The wheat cvs. showed different degrees of susceptibility to the pathogen. The cvs. Buck Arriero, Buck Poncho and Klein Cacique became severely infected with up to $40 \%$ of their leaf surface spotted. The cvs. Prointa Cinco Cerros, Prointa Elite, Prointa Granar and Prointa Imperial were slightly spotted, with $1-5 \%$ of their foliage covered by spots. The cvs. Klein Estrella, Prointa Guazú and Prointa Puntal were free of spots (Table 1). Elongated necrotic yellowish to light-brown lesions could be observed on the upper surfaces of affected leaves of wheat cvs. Leaf spots later coalesced to form large irregular spots with yellow margins (Figure 1). Under high humidity pycnidia developed within spots on leaves after 21 days. A gelatinous spore mass was extruded in cirri from pycnidia.
Table 1. Degree of susceptibility of 10 wheat cvs. to P. sorghina under greenhouse conditions

\begin{tabular}{ll}
\hline Cultivar & Necrotic lesion $(\%)$ \\
\hline Buck Arriero & 40 \\
Buck Poncho & 40 \\
Klein Cacique & 40 \\
Klein Estrella & 0 \\
Prointa Cinco Cerros & $1-5$ \\
Prointa Elite & $1-5$ \\
Prointa Granar & $1-5$ \\
Prointa Guazú & 0 \\
Prointa Imperial & $1-5$ \\
Prointa Puntal & 0 \\
\hline
\end{tabular}

No symptoms or spots were seen in control plants. All wheat plants inoculated with $P$. sorghina in the greenhouse developed symptoms identical to those observed on naturally infected plants

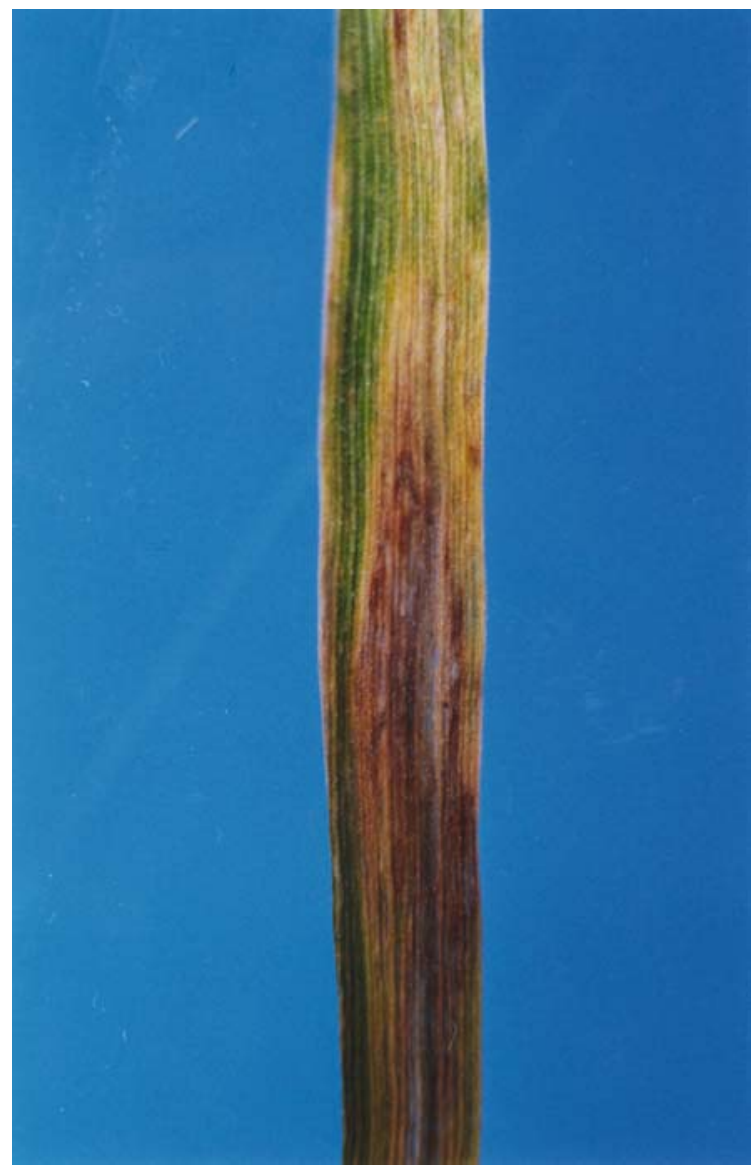

Figure 1. Lesions of P. sorghina on wheat leaf. 
in the field. Reisolation from leaf spots consistently yielded cultures of Phoma sorghina. The isolates were compared with those used for inoculation and found to be morphologically identical to the original isolates and so satisfy the criteria for proving pathogenicity and Koch's postulates. The fungus sporulated on the diseased tissue on PDA plates. In culture the fungus developed dark, greyish colonies with dense aerial mycelium with abundant, solitary or sometimes aggregated pycnidia with characteristic beaks. Conidia were globose to ovoid or shortly cylindrical, usually straight, hyaline, unicellular $4.7 \times 2 \mu \mathrm{m}$. Abundant chlamydospores (Figure 2) and dictyochlamydospores were observed. Newly formed chlamydospores quickly became covered with a black coating that obscured their brown colour.

Ths identification was confirmed by the Centralbureau voor Schimelcultures (CBS), Utrecht, The Netherlands. One representative isolate of $P$. sorghina has been lodged in the CBS culture collection with the accession number 112525 .

Inoculation studies proved that $P$. sorghina was the cause of a leaf spot on wheat in Argentina. The disease expression may be due to new cultural practices such as reduced tillage, nitrogen fertilization, irrigation, the use of new germplasm and favourable weather conditions. These could contribute to a major spread, not only of $P$. sorghina but of the foliar complex of necrotrophic pathogens in general. The fact that $P$. sorghina is found in areas where wheat and non-cereals are grown in close proximity provides ample opportunity for

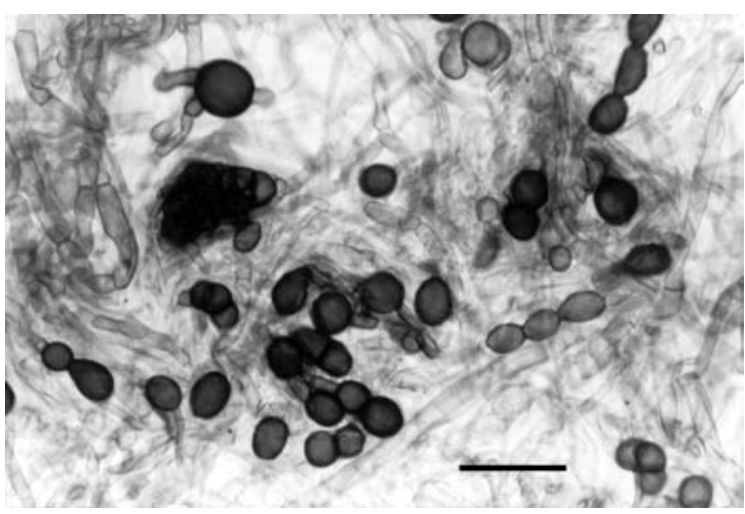

Figure 2. Chlamydospores of P. sorghina on 2\% PDA. (400× Bar. $1.2 \mathrm{~cm}=40 \mu \mathrm{m}$ ). the fungus to disperse from wheat and grow as a saprophyte on other hosts.

Since Phoma spp. have already been found affecting wheat plants in other parts of the world $[9,10,12]$, the finding suggests that the disease also may disseminate in the Argentinian cropping area and could become a potential new constraint to some wheat cultivars in Argentina.

\section{Acknowledgements}

The authors are very thankful to Drs Pedro Crous and Gerard Verkley of the CBS (Centralbureau voor Schimelcultures), The Netherlands, for their kind help to confirm the identification of the fungus.

\section{References}

1. Farr DF, Bills GP, Chamuris GP, Rossman AY. Fungi on plants and plant products in the United States. Minnesota, USA: APS Press, 1989, 1252 pp.

2. Holliday P. A Dictionary of Plant Pathology. Cambridge, UK: University Press, 1989, 369 pp.

3. Kumar PS, Kumar PRP. A new leaf spot disease of Parthenium hysterophorus caused by Phoma sorghina. Indian Phytopathology 2000; 53: 1,115.

4. Manavolta VMA, Bedendo IP. Danos devidos a manchas de grãos em arroz causadas pelos fungos Bipolaris oryzae, Microdochium oryzae e Phoma sorghina, em diferentes epocas de infecção. Summa Phytopatologica 1999; 25 (4): 324-330.

5. Punithalingam E, Holliday P. Phoma insidiosa. CMI descriptions of pathogenic fungi and bacteria. Kew Commonwealth Mycological Institute, 1972; No. 333.

6. Punithalingam, E. Phoma sorghina. CMI Descriptions of Pathogenic Fungi and Bacteria. Kew Commonwealth Mycological Institute, 1985; No. 825.

7. White JF, Morgan-Jones G. Studies in the genus Phoma. II. Concerning Phoma sorghina. Mycotaxon 1983; 18: 5-13.

8. CBS (Centralbureau voor Schimelcultures) Fungi Database Phoma sorghina (Saccardo) Boerema et al. (http:// www.cbs.knaw.nl/scripts/CBSFungi.) Fungi 2003.

9. Diehi JA, Oliveira, Mar de, lgarashi S, Reis EM, Mehta YR, Gomes LS. Survey of root diseases of wheat in Parana. Fitopatol. Brasileira 1984; 9 (2): 179-188.

10. El-Meleigi MA, El-Rokaiban AA, Ibrahim GH, EI Shair SM, Al-Omir ME. Diseases and pests outbreaks in Saudi Arabia. Survey of wheat diseases. In central Saudi Arabia, Arab and Near-East. Plant Protection Newsletter 1994; No. $18,30,5$.

11. Gonzalez HHL, Martinez EJ, Resnik SL. Fungi associated with sorghum grain from Argentina. Mycopathologia 1997; 139: 35-41. 
12. Hosford RM. Jr Phoma glomerata, a new pathogen of wheat and triticale, cultivar resistance related to wet period. Phytopathology 1975; 65: 1236-1239.

13. Wiese MV. Compendium of wheat diseases. Minnesota EEUU: APS Press, 1985, 106 pp.
Address for correspondence: Dra. Analía E. Perelló, Centro de Investigaciones de Fitopatología, Facultad de Ciencias Agrarias y Forestales, Universidad Nacional de La Plata, CC 31, CP 1900, Argentina

Fax: 00-54-221-4252346; E-mail: anaperello@yahoo.com.ar 